\section{(C) 1984 ISIJ \\ 薄鋼板の再結晶及び集合組織研究における 今後の問題}

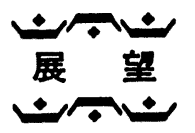

弘*

\title{
Future Problems on Recrystallization and Texture of Steel Sheets
}

Hiroshi TAKEchI

\section{1. 緒}

薄鋼板（以下薄板と略す）の深絞り性がその集合組織 によつて支配されるという BURNS と HEYER ${ }^{1)}$ の指摘 に端を発してから約 20 年の間に, 薄板の再結晶挙動や 集合組織について世界的に研究が展開されてきたことは 周知のとおりである.

BCC 金属の再結晶挙動や集合組織に関する工業的研 究はそれ以前から珪素鋼 $(3 \% \mathrm{Si}-\mathrm{Fe})$ について精力的に 行われて拉り，薄板の場合も原理的な基盤は珠素鋼の研 究を参考としてスタートした．しかし薄板の場合は(1) 変態を考慮せねばならぬこと（2)対象が一次再結晶で あること（3)制御目標が板面に $\{111\}$ 方位を増加させ $\{100\}$ 方位を減少させることなどの点で珪素鋼とは異な つており，薄板研究者は珠素鋼とはほとんど独立してあ らゆるデータを自ら作り出してゆかねばならなかつた.

こうした背景を受けて昭和 45 年 4 月に日本鉄鋼協会の 鉄鋼基礎共同研究会に再結晶部会が設立され，じらい4 年間東大阿部教授の御指導の下に研究発表や討議が行わ れその成果は昭和 49 年 9 月に「鉄鋼薄板の再結晶及び 集合組織」(I) (II) として刊行されたことは周知のとお りである.この成果は薄板の再結晶及び集合組織制御に 関する基礎から応用まで幅広い研究を含んでおり現在で も世界に誇り得るものと思うが，またこの昭和 45〜50 年といらのは薄板にとつて大きな転換期でるあつた。す なわち, (1)連続焼鈍プロセスの工業化，（2)オイルシ ョックに基づく高張力薄板の開発 がいつせいにスター トした時期である．この二つは再結晶や集合組織といら 観点からしても当時ほとんど未知の分野であつたがそれ だけに実用化のテンポの早さとあいまつて関係者は多量 のテーマと試験に忙殺されるよらになつた．また，前記 再結晶部会が解散した時期でもありその後の約 10 年間 はどちらかといえば工業化研究が先行して基礎的研究が 看過されてきたよらな気がする．今年からまた日本鉄鋼 協会に阿部教授を指導者として低炭素鋼板研究会が誕生 したことはまさに時宜を得たものであり, 嵐が通り過ぎ
たようなこの 10 年間にやり残した原理原則的な研究や 討論がじつくりと腰を据えて行われることを切望するる のである.というのも我々は現在, 連続焼鈍や高張力薄 板に続いて次の革新は何か，そしてそのシーズは何か, を考え直す新しい転換期に差しかかつており，今こそ薄 板研究の原点に帰つた基本的な研究が必要であると考え られるからである.

本特集号では多くの秀れた執筆者がそれぞれの専門分 野について詳細な解説や指摘を行われるであろらからあ 光て私が蛇足を付け加えることすないような気がする が, 編集委員会の御指名でああるので今後の議論の吒き 台とする心算で独断と偏見に満ちた問題提起を 2,3 行 つてみたい.

\section{2. 蕃楼エネルギーの方位別定量評価}

再結晶核の発生は圧延された matrix 中の蓄積エネル ギー (Stored Energy, 以下 SE と略す) の量とその回 復速度に依存するのでまずこの二つを結晶方位別に, 定 量的に知らねぱならない。このことは再結晶の素過程を 知る上で重要であるが，集合組織制御のために添加する 第二相成分の役割を理解する上でも甚だ重要である．第 二相成分のことは 4 章で触れる.

圧延など加工によつて導入された転位は AsHBY2) の表 現を借りれば Statistically distributed dislocation と Geometrically necessary dislocation に分類される. 前 者は短範囲に $(+)$ と（一）が分布し回復初期に消隇す るものであるが, 後者は局在する転位いわゆるInhomogeneous dislocationで, 回復後期に消滅しながら再結晶 核を形成するものである．SE は加工後の総転位量とい う意味から両者の和であるが再結晶機構を論じる時必要 なのは後者であつて，我々は後者を定量的に，方位別に， 比較的容易に，知る手段を考えねばならない，SE 測定 法の例を表 1 に示した．熱量計によつて測定されるのは Statistically distributed dislocation ¿ Geometrically necessary dislocation の和であり, 熱量計によつて後者 だけを方位別に分離することは不可能なのでここでは省 
表 1 蓄積エネルギーの評価法

\begin{tabular}{|c|c|c|c|}
\hline & 方 & 定 & 測定値の意味, 問題点 \\
\hline 熱讋計 & 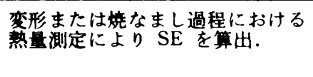 & $\begin{array}{l}\mathrm{Cu} \sigma \text { 室温引張 } \\
10.5(10 \%) \sim 26(33 \%) / \mathrm{g} \cdot \text { atom } \\
\text { (変形に要した全仕事量の) } 2 \sim 10 \% \text { 程度) }\end{array}$ & 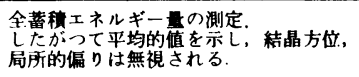 \\
\hline $\begin{array}{l}\mathrm{X} \text { 線回折線ブロファイル } \\
\text { 解 }\end{array}$ & 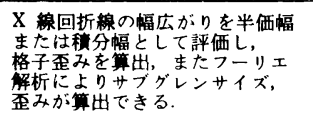 & 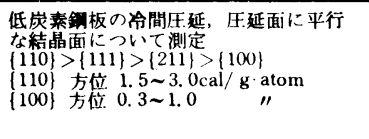 & 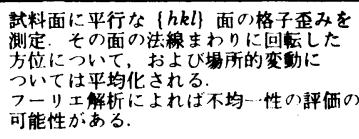 \\
\hline Kossel（コッセル） 法 & 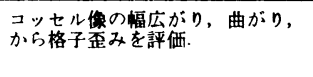 & & 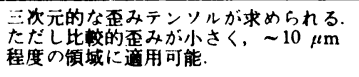 \\
\hline 透過電子顆徵鏡 & $\begin{array}{l}\text { サブグレンのサイズ，境界角度 } \\
\text { より蓄皘エネルギー蕒什. }\end{array}$ & 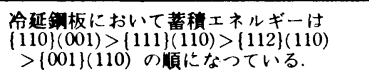 & 梳計的に有意な測定が必要。 \\
\hline
\end{tabular}

略し, X 線回折線プロファイル解析法(以下 LP 法と略 す）と透過電子顕微鏡法（以下 TEM 法之略す）につい て簡単に触れたい。

LP 法では回折角を $\theta$ とすると $\sin ^{2} \theta$ と幅広がり量 の直線関係に括ける幅広がり量軸の截片から結晶方位別 に Subgrain のサイズと境界角度 (Misfit angle) に関 する情報を得ることが可能であり，これらはInhomogeneous dislocation に対応するものである. もし変形帯の ように局所化した転位密度の高い領域が少なければ LP 法の情報は希釈されてしまつてあまり役に立たないが， 冷延圧下率が $60 \%$ 以上と大きくて局所化した高転位密 度領域の比率が高い薄板の場合には, LP 法はかなり的 確に再結晶核発生サイトの情報を伝えていると考えられ る. 例えば TEM 法で測定した圧延方向に〈110〉軸を 持つ方位系列の SE は大きい方から (110) [110]>(11̄1) $[110]>(\overline{1} 12) \quad[110]>(001) \quad[110]$ の順になつている が3), LP 法で求めた順位も $\{110\}>\{111\}>\{112\}>$ $\{100\}$ であり4)両者は良く一致し，また再結晶後これら 方位の増減傾向と前記 SE の大小関係とは極めて良く対 応している.これらの測定結果から泠延板における $\mathrm{SE}$ 分布の方位依存性は図 1 のように模式化されよう。すな わち方位によつて SE の絶対值やその幅, 分布状態は異 なるがその平均値の差は LP 法によつて検出される.

図中，方位 $\mathrm{A}$ と方位 $\mathrm{B}$ の $\mathrm{SE}$ 差が小さければ二つの分布 曲線は部分的に重なつて再結晶核化速度の比較はできな くなるが，上述のように TEM 法と LP 法における SE の大小関係が一致していることから，冷延された薄 板の内部では図 1 のように上記主要面結晶方位間では SE の十分な有意差が存在するか，あるいは SE の有意 差が十分に存在する方位が幾何学的に隣接して存在する ものと考えられる.ただ LP 法については一つはつき りさせておかなければならぬ問題がある。それは例えば 板面に平行な回折面の LP 測定值はその結晶が三次元 的に保有する SE を必ずしも示するのではない, という ことである.これに対する一つの提案として例えば三 次元極点図で特定方位の存在を確認しておき，面法線

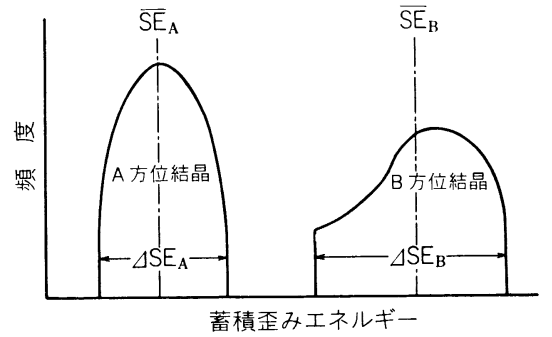

四 1 圧延による蓄積昰みエネルギーの方位依存性 (ND) 圧延方向 (RD) 幅方向 (TD) 3 方向から LP を測定して立体的に SE の方位別分離を試みてはどらか と考劣る. 更にいえば LP 法のもら一つの欠点である $\mathrm{SE}$ の不均一性の分離は, 回折線のフーリエ解析によつ てかなり多くの情報が得られるのではないかと思われ る. LP 法には上述した欠点があるにもかかわらず一方 では棄て難い魅力がある. それは LP 法によれば SE を結晶方位別に, 定量的に測定でき，かつ測定やデータ 処理が比較的簡単だといらことである.

一方 TEM 法では結晶方位を確認した場所における 局所的な転位密度を測定している点信頼度は十分である が, 測定法自身が煩雑である上多数の場所について測定 を行つて統計的に判断しないと全体傾向を誤認する危険 がある. かつて P. B. HIRSGH の研究室では TEM に よる薄膜写真を多数撮つて八畳敷くらいの大きさに貼り 合わせ，その中から最も全体傾向を代表していると思わ れる個所を鋏で切り出して論文に載せる，といら話を聞 いたことがある. 事実の程は知らないが TEM 法には それくらいの配慮が必要であるといら話であろら．

試験条件の数が多い工業材料の開発では煩雑な手法は とかく敬遠される．これが工業材料に括ける再結晶や集 合組織制御のメカニズムを解明する上でかなり大きな障 害となつていると思うが, 一方測定法として敩密性を欠 くものではいかに簡便だといつてもそれなりの意味しか ない，筆者がここでいいたいことは簡便でかつ信頼でき る結晶方位別 SE の測定法を確立することが集合組織制 
御のメカニズムを明らかにし，新材料の開発を促進する 上で重要な問題ではないか, といらことである.

\section{3. 結晶方位別の再結晶速度論}

一般にある現象の進行を考兵る時には他現象との競合 関係すなわち速度論が必要になるが, 集合組織制御の場 合も特にこれが必要である.

恒温下の再結晶の進行についてはよく知られた AvramI の式がある.

$$
X(t)=1-\exp \left[-B t^{K}\right]
$$

ここで $X(t)$ は時間 $t$ に打ける再結晶分率, $B, K$ は 定数である. また, 温度を变えて再結晶速度を測定すれ ば一般の物理現象と同様に Arrhenius プロットが成り 立つ。

$$
V=V_{0} \exp \left(\frac{-Q}{R T}\right)
$$

ここに $V$ は再結晶速度, $V_{0}, R$ は定数, $T$ は絶対温 度，Qは再結晶の活性化エネルギーである.

これらの式を光学顕微鏡規模で一次再結晶粒の発生, 成長に適用した例はずいぶんたくさんあるが結晶方位別 に測定してその Kinetics を論じた例は少ない，等温再

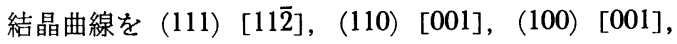
(100) [011] 方位について描いた HiBBARD-Tully ${ }^{5}$ ) の 研究などはあるが従来方位別の速度論として扱われたも のの多くは Oriented growth theory に関するもので FCC なら〈111〉軸, BCC なら〈110〉軸周りの回転関 係を持つ粒界の移動速度に関する研究である. しかし工 業材料の集合組織制御を考える時には例えば変形帯や旧 粒界近傍を matrix とする領域で核発生, 成長する速度 をミクロな方位分布ごとに測定したり，またそれらが第 二相成分によつていかに変化するかといつた速度論的研 究が不可欠であると思う.

ただ（1)式，(2)式いずれの場合をとるにせよ核発生 と成長の期間の識別が難しい.（1) 式の定数 $B$ には核発 生速度 $\dot{N}$ と成長速度 $\dot{G}$ の両方が含まれ (2) 式の活性化エ ネルギーQにも普通の測定法では $\dot{N}$ と $\dot{G}$ の両方を含んだ 值となる.しかし核発生と成長とを厳密に区別できなく ても再結晶粒の発生 site は変形帯や旧粒界近傍が多い
から少なくとも種々の方位についてこれら領域の $\dot{N}+\dot{G}$ またはQと結晶中央部のそれらとを微視的に区別した測 定ができれば再結晶集合組織形成に定量的な議論を持ち 込むことが可能となるであろう.

微視的領域の歪み解放過程や再結晶過程を測定するこ とは非常に難しいが, 例えば従来の微少硬度計より荷重 がもら 1 桁小さい超微少硬度計が開発されれば Etch pit 法と組み合わせてある程度の粗大粒には使用できると思 われる. また微少領域の集合組織を Etch pit 法より定 量的に測定するためにX線強度を強めて視野を制限した 微少領域極点困 (Micro pole figure) 測定装置が開発さ れれば，上記歪みの解放過程の測定と併せて解析はもつ と進むであろう. 特定方位の核発生力や成長力を定量的 に評価することは次項に述べる第二相成分の抑制力に関 連して重要なことであり研究目標として提案したい.

\section{4. 第二相成分による集合組織制御 メカニズム}

一般に工業材料の集合組織制御には鋼中に第二相成分 を添加して行うことが多い. 第二相成分は被亘食粒の成 長を抑制する物といら認識から一般に Inhibitor と呼ば れることが多いがそれ以外にもいろいろな考えが提案さ れているのは周知のとおりである. 表 2 は再結晶部会で 報告された事例6) 16) の中から第二相成分に関する異な つた考え方を抽出したものである.

ここで，(1) 前析出型といらのは第二相成分が冷延前 に析出物として既に存在し, それらが冷延集合組織のミ クロな方位分散や SE を変化させるか, 焼鈍再結晶時 に粒成長の選択的抑制力として働くという考えであり,

(2)後析出型というのは冷延後焼鈍時に第二相成分が析 出して特定方位の再結晶核生成 ·成長を優先的に行わせ るという考えである.また，(3) Scavenging 型というの は matrix から固溶元素を析出·無害化させて優先再結晶 粒の成長を円滑に進行させるとするものであり，(4)純 鉄説というのは侵入型固溶元素の 存在しない冷延 matrix からは本来 $\{111\}$ 方位が優先成長するといら考えで ある.こうしたいろいろな考え方が提案されてはいるる のの残念なことに現在どれか一つに決着がついているわ

表 2 第二相成分による集合組織制御の考え方

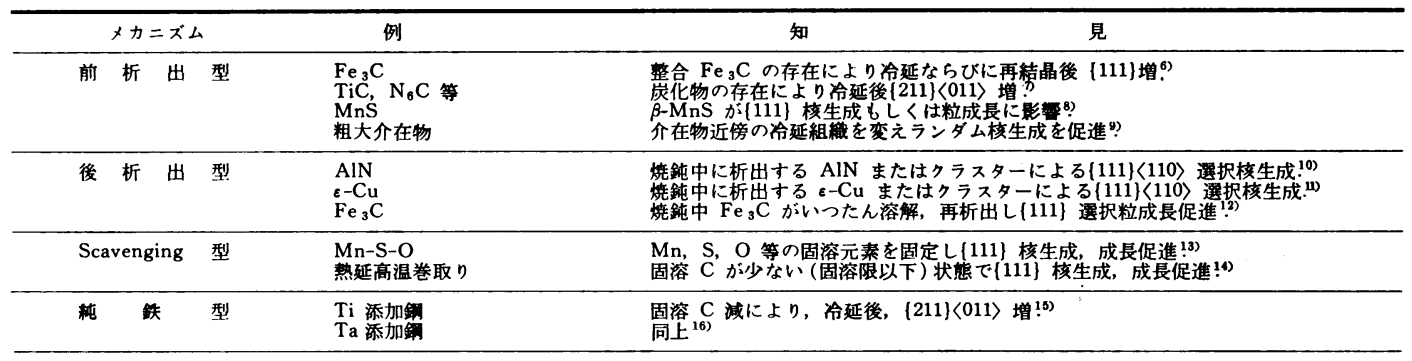


けではない，その理由は考え方を直接立証する手段に適 当なるのがほとんど無いということ, 定量的な議論が少 なかつたといらことなどにあると思われる。

しかしいずれにせよ再結晶集合組織形成は冷延後 SE の方位依存性とその解放速度や冷延後存在する方位分布 に依存しているから，例えば前析出型や純鉄説に対して は冷延後の SE やミクロな方位分散に対する定量的測定 法があれば事態はかなり明瞭になるし，また後析出型や Scavenging 説については冷延後 SE すなわち再結晶の 駆動力之第二相成分の抑制力との定量的比較ができれば かなり見通しはついてくるであろう。

ここでは例として再結晶の駆動力と第二相成分の抑制 力との比較について簡単に触れてみたい.

一般に第二相成分が半径 $r$ の 球状粒子である場拿 Zener drag として知られる粒成長抑制力 $F$ が働く.

$$
F=-\frac{2 \gamma_{\mathrm{B}} f}{r}
$$

ここで $\gamma_{\mathrm{B}}$ は粒界ェネルギー, $f$ は第二相成分の Volume fraction である. 第二相成分が析出粒子よりし だいに小さくなると次の形態をとると考えられる。

$\underset{\text { (Precipitate) }}{\stackrel{\text { 析出粒子 }}{\longrightarrow} \text { Pre-precipitate }} \longrightarrow$ Dipole $\underset{\text { (Solute atom) }}{\longrightarrow \text { 溶質原子 }}$

すべての Precipitate が Cluster やDipole になるわけ ではなく,すべての Cluster が Dipole になるわけでない のはもちろんである.（3)式で $f$ を溶質原子濃度, $r$ を 原子半径とするとZener drag を一応溶質原子にまで拡 大できる17). Dipole については近年阿部教授によつて 置換型固溶原子と侵入型固溶原子のペアから成る Dipole (例えば Mn-C) の存在が熱電能測定から明らかに なつた ${ }^{18)}$ 。これは析出粒子よりも影響する範囲が広く，

溶質原子よりも抑制力が強いと考えられるから工業的利 用を含めて非常に興味ある問題である。

しかし Dipole や Cluster の抑制力をどのように評価 するか，すなわち溶質原子のように転位が引き摺つて動 かせるものと，析出粒子のよらに動かせないものの中間 体の抑制力をどのように評価するかは今後の重要な問題 であろう・

再結晶の駆動力 $M$ は粒界エネルギーを考慮しなけれ ばその領域に冷延後導入された転位密度 $\rho$ によつて

$$
M=G b^{2} \rho
$$

と表される.ここで $G$ は凰性率， $b$ は Burgers Vector である.（4)式の $\rho$ はこれまで議論してきた SE に 対応するものとすると図 1 を再結晶の駆動力に書き直し て図 2 のように表現できる，もし第一相成分の抑制力が 定量的に表現できるとすれば図 2 の一捙の冷延方位の再 結晶駆動力スペクトルの中に抑制力の Gate を書き込を ことができるから優先方位のコントロールについてょり 定量的議論ができるようになるであろう．第二相成分が 冷延後の SE ほ ク口な方位分散を変元る可能性も含め

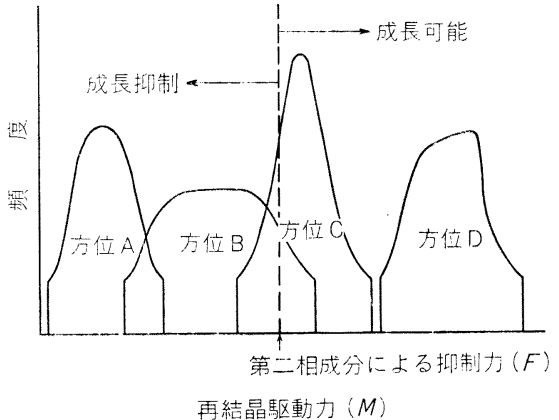

図 2 再結晶駆動力の方位依存性之第二相成分によ る粒成長抑制力の関係

て再結晶駆動力と抑制力の定量的評価や議論が活発に行 われることを期待したい。

\section{5. 圧延条件が結晶回転及び蓄稓 エネルギーに及ぼす影響}

近年圧延機の著しい進歩によつて圧延様式や圧延条件 の変化は目覚ましいものがあり,こうした变化が結晶学 的にどのような影響をるたらすか，逆に結晶学的立場か らどのような圧延様式を希望するか，などを考慮すべき 時代になつた。しかし新しい圧延機を持ち出すまでもな く従来から圧延といら変形様式と結晶回転, 特に板厚方 向の結晶回転の変化, との関係は十分解析されていたと はいい難い．圧延が再結晶の素地を作るプロセスである 以上これは重要な問題であり二次再結晶粒のルーツまで 含めて今後理論的にも実験的にも十分検討が行われるべ きであろう.この方面の話題について少し触れてみたい.

圧延による結晶回転を考察する時一般には昰みのみを 採り上げるが，実際の圧延には巨視的歪みとして剪断歪 みを伴つている.すなわちロールバイトの入側ではロー ルと材料の相対的速度差により内向きの摩擦力が発生し 出側では外向きの摩擦力を生ずる. 材料とロールの速度 が一致する点が中立点で摩擦力は 0 である. この摩擦力 によつて板の表裏では逆向きの剪断力が生じ板厚中心で は 0 になる. 主歪みに対し前断昰みが小さければ変形を 平面歪みとして取り扱つてよいが圧延条件の大幅な変化 によつては剪断歪みの影響を無視できなくなる，例えば 非対称圧延では Back tension が変化して中立点は移動 するし, Work roll の径や 1 パス圧下率の変化によつて 剪断查みの板厚方向一の影響範囲が変化する.

同一圧延率でも多パス圧延では頁断昰み $\gamma$ は小さい から図 3 の点線で示されるように入側出側で剪断歪みの 影響を相殺しながら $\gamma=0$ の時に定められた方向に向か つて方位空間の中を結晶回転していくことになるが，1 パス大压下生延になると図 3 の実線で示されるように多 パス压延とは違つた結晶回転を残す。これはロール入側 の剪断力によつで集合組織が形成されッール出側で逆向 


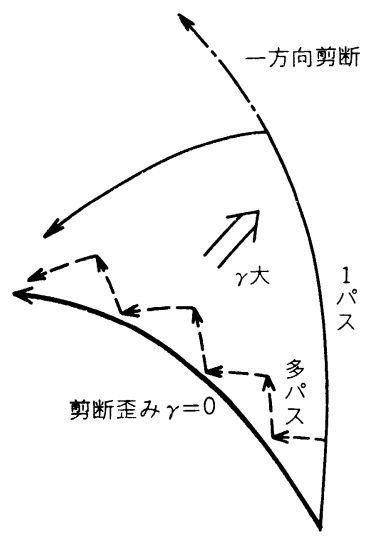

困 3 全圧下率一定の場合の 1 パス圧延と多パス圧 延による結晶回転

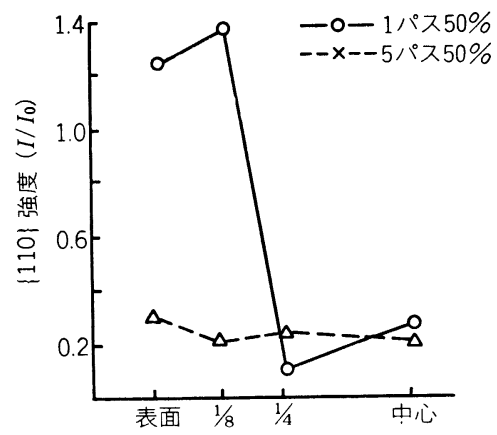

図41 1 次冷延圧下率による冷延後 $\{110\}$ 強度の 変化（ロール径 $25 \phi$, dry 圧延）

きの萁断力が作用する際の方位が初方位と既に異なるこ とによる. 図 4 に全圧下率 $50 \%$ を1 パスで圧延した場 合と 5 パスで圧延した場合の板表面から板厚中心までの $\{110\}$ 方位分布が示されている ${ }^{199} .1$ パス大圧下された 場合は剪断変形によつて板表面部の結晶回転が阻害され $\{110\}$ 方位は残存するが, 多パス圧延では結晶回転を生 じて激減したものと思われる．また図 5 には Work roll 径によつて冷延焼鈍後の $\overline{\boldsymbol{r}}$ 值が顕著に変化する状況を示 す20). ロール径が $60 \mathrm{~mm}$ と小さい場合, 冷延後板表面 部では剪断変形によつて $\{110\}$ 方位が多く $\{222\}$ 方位 が少なくなることが報告されている．熱延の場合はロー ルと板表面の Sticking が強いので冷延に比べると剪断 成分はかなり強い，このような板厚方向の主昰みと剪断 歪みの比やそれに基づく結晶回転の変化を明らかにし, またそれが後の再結晶集合組織形成にいかに影響するか を明らかにするため，第二相成分を含有したり，あるい は含有しない単結晶を圧延条件を変えて冷延あるいは熱 延をして, 板厚方向の結晶回転や SE の変化を測定する ことは非常に意味のあることである. 最近単結晶を使用 した研究はあまり行われなくなつたが，例えば今述べた

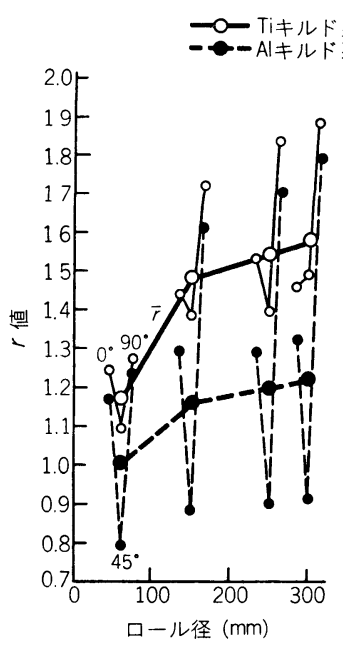

(a) 冷延圧下率 $67 \%$

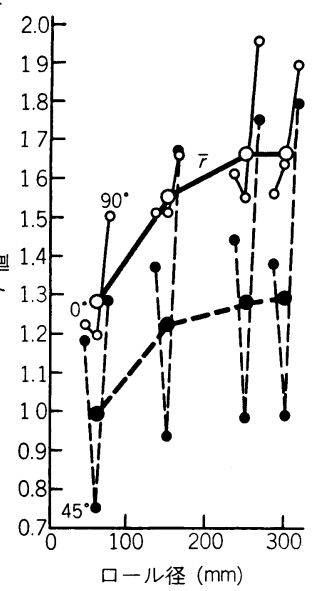

(b) 冷延圧下率 78\%
図 5 冷延焼鈍後の $r$ 值に及ぼす Work rolll 径 の効果

ような観点からの検討を提案したい.

\section{6. 解析手段の開発}

これまでも触れてきたように再結晶, 特に集合組織制 御の研究において必要なことは, 結晶方位ごとに異なつ て生ずる現象の定量化とその現象を直接検証する手段の 開発である.

これまでも集合組織研究にはX $\mathrm{X}$ 線や透過電顕を始め多 くの測定, 解析手法が開発されそれらは極めて多くの知 見を我々にもたらした. 装置や解析手法の開発こそが新 しい知見の扉を開く鍵であり，それらが無い議論はとも すれば定性的な，推測的なものになつてしまう。

表 3 には再結晶及び集合組織研究に必要と思われる必 要情報と解析手段を示した. 解析手段には装置と手法が 含まれるが，表中 口印で囲つたものは現在未確立かま たはもつと改良を必要とすべき項目ないしは解析手段で ある. あちろん解析装置の開発には専門メーカーの努力 による所が大であるが，これまです我々がそうしてきた ように研究現場からの強いニーズが新しい装置を産む駆 動力となるのであり両者のスムースな情報交換, 協力態 勢がー一段と期待される.

\section{7. 結}

言

薄鋼板の再結晶や集合組織の研究はこれまでいろいろ と行われてきたけれども基本的な問題になるとわからな いことがまだ随分残つている. 現象を利用することのみ に急であるばかりでなく，これらは鉄鋼の基本的性質で あるからどつしりと腰を据えて, 着実に研究を継続する ことが望まれる. 新しい製品の開発や新しい特性の発見 にも結局それが近道であると信ずる次第である. 
表 3 再結晶および集合組織研究に必要な項目と解析手段

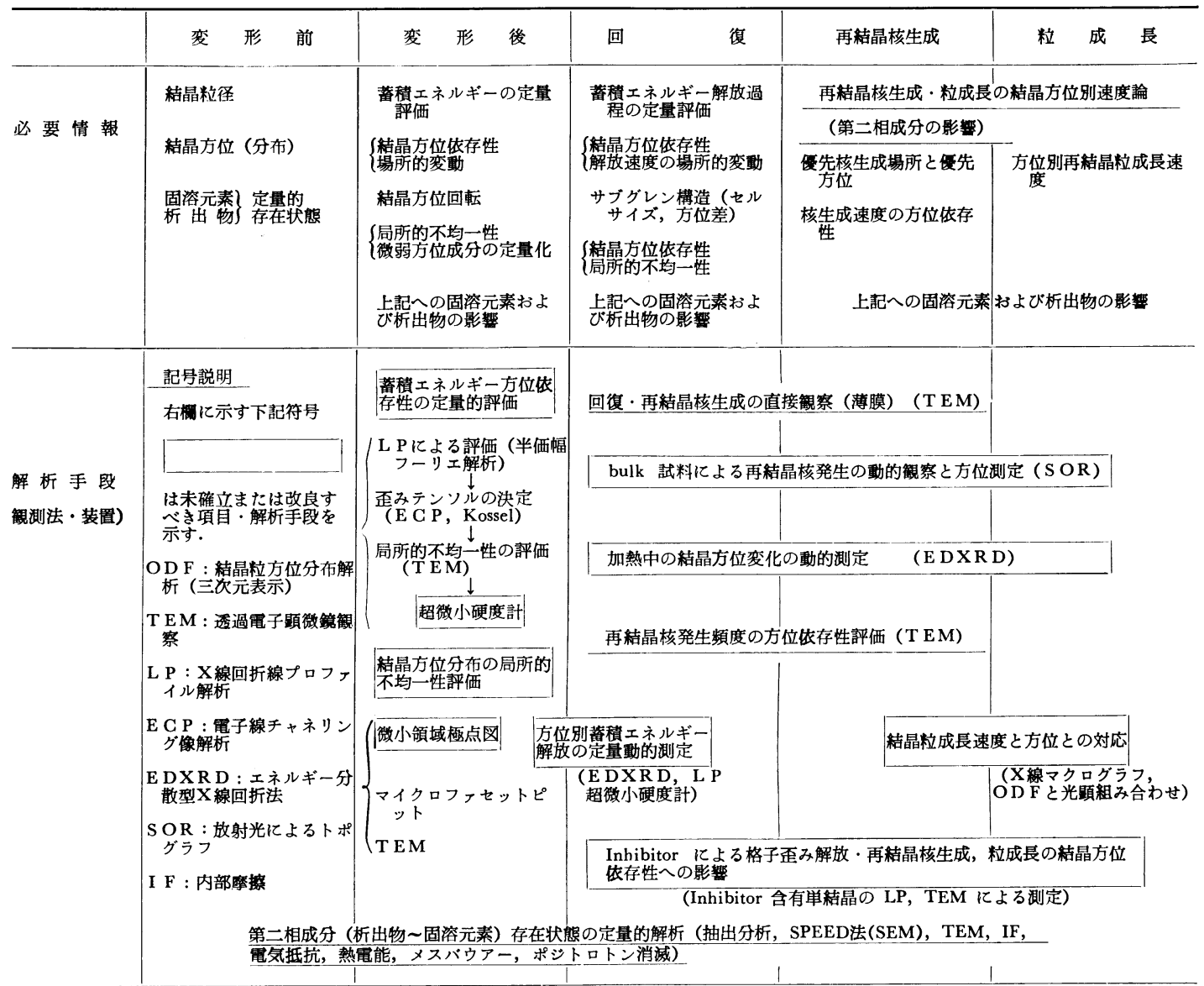

\section{交献}

1) R. S. Burns and R. H. Heyer: Sheet Metal Ind., 35 (1958), p. 261

2) M. F. Ashby: Phil. Mag., 21 (1970), p. 399

3 ) I. L. Dillamore, $C . J . E$. Smith and $T . W$. Watson: Met. Sci. J., 1 (1967), p. 49

$4) H$. Takechi, $H$. КатоH and $S$. Nagashima: Trans. Metall. Soc. AIME, 242 (1968), p. 56

5 ) $W . R$. Hibbard and $W . R$. Tully: Trans. Metall. Soc. AIME, 221 (1961), p. 336

6 ) 阿部秀夫, 高木甲子雄: 鉄と鋼, 57 (1971), p. 1123

7 ) 秋末 治, 高階喜久男: 日本金属学会誌, 36 (1972), p. 1124

8 ）日本鉄鋼協会鉄鋼基礎共同研究会：第 3 回再結晶 部会 (1971 年 7 月) 新日本製鉄(株) (私信)

9 ) $W . C$. Leslie, $J . T$. Michalak and $F . W$. AuL: Iron and its Dilute Solid Solutions (1963), p. 119 [Interscience, New York]

10) 白岩俊男, 寺崎冨久長, 小玉 強: 日本金属学会 誌, $35(1971)$, p. 20

11）鉄鋼薄板の再結晶及び集合組織 ( I ) (鉄鋼基礎共
同研究会再結晶部会編) (1974)，p. 135 [日本鉄鋼 協会]

12）大橋延夫，小西元幸，有馬与志広：川崎製鉄技 報， 5 (1973) 2, p. 164

13) 戸田健三, 西脇 実, 権藤 永, 武智 弘, 阿部 光延：鉄々銅，59(1973), S 497

14) 久保寺治朗, 中岡一秀, 荒木健治, 渡辺㢣, 岩 瀬耕二: 鉄と鋼, 62 (1976), p. 846

15）高橋延幸, 清水峰男, 長田修次, 武智 弘: 日本 金属学会講演概要 $(1971)$, p. 10

16) 鉄鋼薄板の再結晶及び集合組織 ( I ) (鉄鋼基礎共 同研究会再結晶部会編) (1974), p. 99 [日本鉄 鋼協会]

17) H. P. Stüwe: Recrystallization of Metallic Materials (1978), p. 15 [Dr. Riederer-Verlag]

18）阿部：熱電能測定による低炭素鋼の加工および熱 処理プロセスの研究, 昭和 57 年度科学研究費補 助金 (一般研究 B) 研究成果報告書 (昭和 58 年 3 月)

19）加藤 弘：私信

20）河野彪，佐柳志郎，中島浩衛：鉄と鋼， 68 (1982), p. 58 